Research Report No. 22/2012

\title{
Debt or Equity? A Puzzle for Canadian Bankruptcy Law
}

Stephanie Ben-Ishai

Osgoode Hall Law School of York University, sbenishai@osgoode.yorku.ca

Follow this and additional works at: http:/ / digitalcommons.osgoode.yorku.ca/clpe

\section{Recommended Citation}

Ben-Ishai, Stephanie, "Debt or Equity? A Puzzle for Canadian Bankruptcy Law" (2012). Comparative Research in Law \& Political Economy. Research Paper No. 22/2012.

http://digitalcommons.osgoode.yorku.ca/clpe/25 


\section{OSGOODE}

OSGOODE HALL LAW SCHOOL

YOR K U N I VERSITY

\section{OSGOODE HALL LAW SCHOOL}

Comparative Research in Law \& Political Economy

RESEARCH PAPER SERIES

Research Paper No. 22/2012

\section{Debt or Equity? A Puzzle for Canadian Bankruptcy Law}

Stephanie Ben-Ishai

\section{Editors:}

Peer Zumbansen (Osgoode Hall Law School, Toronto, Director, Comparative Research in Law and Political Economy) John W. Cioffi (University of California at Riverside)

Leeanne Footman (Osgoode Hall Law School, Toronto, Production Editor)

Comparative Research in Law \& Political Economy 
Osgoode CLPE Research Paper 22/2012

Vol. 08 No. 05 (2012)

\title{
Stephanie Ben-Ishai
}

\section{Debt or Equity? A Puzzle for Canadian Bankruptcy Law}

\begin{abstract}
With the increased sophistication of financial markets and financial instruments, the use of hybrid investments has been on the rise in recent decades. This article considers the question of how Canadian courts have drawn the border between debt and equity in the context of bankruptcy proceedings. The basic argument is that Canadian courts should allow the recent reforms to bring about their intended clarity on the border between debt and equity by not departing from the bright line test set out in the legislation. The article compares the pre and post-amendment case law and uses two case studies to illustrate the undue complexity that has been created by layering a contextual analysis on top of the new bright line tests. Simply put, in the context of investment classification decisions for the purposes of bankruptcy proceedings, Canadian courts should limit the scope of their analysis to an inquiry of whether the investment in question falls within the scope of the "equity claim" definition provided under Canadian bankruptcy legislation. Only then can bankruptcy costs be limited and can we come closer to a model assumed by the ModiglaniMiller Theorem.
\end{abstract}




\section{Introduction}

The Modiglani-Miller theorem or the "capital structure irrelevance" principle (the "MM Theorem") suggests that in an efficient market, it does not matter if the firm's capital is raised by issuing stock or selling debt. ${ }^{1}$ Essentially, the MM Theorem suggests that firms should focus on the net present values of each investment rather than the composition of their capital. ${ }^{2}$ The MM Theorem acknowledges that capital structure is only irrelevant under a certain market price process which includes the absence of bankruptcy costs. ${ }^{3}$ However, when the relevance of bankruptcy costs is taken into account, the capital structure of the firm also becomes relevant. Firms that are highly leveraged by debt theoretically have an increased chance of experiencing financial distress which can lead to the expenditure of hefty bankruptcy costs, decreasing firm value. ${ }^{4}$ Determining the nature of a firm's capital structure is significant in assessing bankruptcy costs and structuring transactions. However, this is not a simple exercise in many instances. To this end, recent reforms to Canadian bankruptcy legislation sought to clarify the distinction between debt and equity for the purposes of bankruptcy and restructuring proceedings.

With the increased sophistication of financial markets and financial instruments, the use of hybrid investments has been on the rise in recent decades. ${ }^{5}$ This development supports the need for the "equity claim" amendment - an attempt to codify the definition

\footnotetext{
*The research assistance provided by Emily Uzza (Osgoode JD, 2014) is gratefully acknowledged.

${ }^{1}$ Franco Modigliani \& Merton H Miller, "The Cost of Capital, Corporation Finance and The Theory of Investment" (1958) Am Econ Rev 261 at 268-269.

${ }^{2}$ Albert Banal-Estañol, Chapter 1: The Modigliani-Miller Propositions, Taxes and Bankruptcy Costs, Lecture notes, (Universitat Pompeu Fabra and Barcelona Graduate School of Economics, January 2010) at 7.

${ }^{3}$ Banal-Estañol, supra note 2 at 20.

${ }^{4}$ Banal-Estañol, supra note 2 at 28.

5 Jason Harris \& Anil Hargovan, "The Intersection Between Shareholders' and Creditors' Rights in Insolvency: An Australian Perspective" [2007] Ann Rev Ins L 699 at 704.
} 
and treatment of debt and equity under Canadian bankruptcy legislation. These hybrid investments combine elements of both debt and equity. Prominent examples of hybrid investments include redeemable preferred shares, convertible debentures, debentures which have their interest rate tied to the performance of one or more equities, income securities, and debentures with attached warrants, among many other variations. From the perspective of the issuers, hybrid securities appear to have grown in popularity because they allow issuers to achieve a lower cost of capital than would otherwise be achievable under separate issues of debt and equity. ${ }^{6}$ From the perspective of the investor, hybrid securities have presumably grown in popularity because they allow investors to experience the benefits of both debt and equity, combined within one financial instrument.

Because hybrid instruments contain debt and equity characteristics of varying magnitude, it is difficult to pigeonhole them into debt or equity categories. ${ }^{7}$ However, the classification of an instrument as debt or equity is crucial in the context of bankruptcy; the classification determines whether an investor will be ranked along with creditors in bankruptcy proceedings or whether they will be subordinated to the creditors, unlikely to receive a distribution in a bankruptcy proceeding. Despite various policy arguments in disagreement with the concept of blanket subordination of equity, the equity amendment codifies the subordination of equity claims in a manner that is even more strict than other

\footnotetext{
${ }^{6}$ Tyrone M Carlin, Nigel Finch \& Guy Ford, "Hybrid Financial Instruments, Cost of Capital and Regulatory Arbitrage - An Empirical Investigation" (2006) 1 J App Res Acc \& Fin 43 at 47.

${ }^{7}$ Andriy Krahmal, "International Hybrid Instruments: Jurisdiction Dependent Characterization" (2005) 5 Hous Bus \& Tax LJ 1 at 6.
} 
jurisdictions such as the US; ${ }^{8}$ the amendment and corresponding jurisprudence appear to make clear that equity will be subordinated to debt without exception.

This article considers the question of how Canadian courts have drawn the border between debt and equity in the context of bankruptcy proceedings. The basic argument is that Canadian courts should allow the recent reforms to bring about their intended clarity on the border between debt and equity by not departing from the bright line test set out in the legislation. Following this Introduction, Part II provides an overview and a rational for the recent amendments to Canadian bankruptcy legislation that have codified the distinction between debt and equity. Part III considers how Canadian courts treated the distinction before the reforms and compares this case law to the treatment following the reforms. Part IV provides two case studies to illustrate why the post-amendment approach without further judicial intervention is superior to both the pre-amendment and postamendment approach taken by the courts. Part V concludes.

\section{Defining Debt and Equity under the BIA and the CCAA}

In September 2009, two specific amendments to the Companies' Credits

Arrangement Act (CCAA) and the Bankruptcy and Insolvency Act (BIA) came into effect. ${ }^{9}$ The first amendment codified the common law doctrine of blanket subordination. ${ }^{10}$ For example, section 6(8) of the CCAA states that "no compromise or arrangement that provides for the payment of an equity claim is to be sanctioned by the court unless it

\footnotetext{
${ }^{8}$ Harris \& Hargovan, supra note 5 at 732 . This article was published prior to the amendments coming into effect. However, the authors' prediction that Canada's subordination of equity after the amendments would be stricter than that of the US was correct. In the US, the courts have flip-flopped regarding the rights of defrauded investors in bankruptcy proceedings because of a lack of clarity in the Bankruptcy Code and other related statutes. However, Canada's approach is much more strict, providing no such exceptions for defrauded investors to this point.

${ }^{9}$ Companies' Creditors Arrangement Act. RSC 1985, c C-36 [CCAA]. Bankruptcy and Insolvency Act, RSC 1985, c B-3 $[B I A]$.

${ }^{10}$ The term "blanket subordination" was identified in: Harris \& Hargovan, supra note 5 at 704 . For the common law doctrine, see Halsbury's Laws of England, vol 3(2), 4th ed (London, UK: Butterworths, 1980) at 315.
} 
provides that all claims that are not equity claims are to be paid in full before the equity claim is to be paid."11 This specific amendment was not particularly contentious; it codified a common law rule of blanket subordination which subordinates the interests of shareholders until after all of the company's creditors had been paid in full. ${ }^{12}$

At the point of insolvency, the relationship between shareholders and creditors can be described as a zero sum game; if the shareholders recouped their capital investment, the returns of the creditors would be diminished and if the company's assets are divided amongst the creditors, the shareholders' investments will be lost. ${ }^{13}$ The common law rule of blanket subordination developed to address these competing interests and to determine in what order the claims would be ranked. Creditors are ranked ahead of shareholders because of the risk of participation associated with each type of investment.

In the simplest formulation, equity holders assume the risk that the value of their investment is contingent on the performance of the company and they also possess some rights of control (i.e. voting rights) to define the risk of the company. Whereas, creditors do not assume that their return is contingent on the performance of the company, nor do they possess the positive control powers held by shareholders. ${ }^{14}$ Because equity holders have taken on this increased risk participation and have assumed the higher risk associated with their investments, they are ranked below the creditors in insolvency proceedings because

\footnotetext{
${ }^{11}$ CCAA, supra note 9 at s 6(8). BIA, supra note 9 at s 60(1.7). Note that the exact language quoted in this text is from section $6(8)$ of the $C C A A$. The language in section $60(1.7)$ of the $B I A$ differs slightly but has the same meaning.

${ }^{12}$ Harris \& Hargovan, supra note 5 at 704 . However, it is unclear whether this provision has been fully applied. See Re Canwest Communications Corp 70 CBR (5th) 1. This discussion is beyond the scope of this paper.

${ }^{13}$ Harris \& Hargovan, supra note 5 at 703.

${ }^{14}$ Robert Flannigan, "The Debt-Equity Distinction" (2011) 26 BFLR 451 at 452.
} 
the creditors have not assumed such risks. However, in order for this analysis to apply, the line between equity and debt needs to be drawn.

The second component of the equity amendment added the definition of an "equity claim" to section 2 of each of the $C C A A$ and the $B I A$ - a definition which was previously nonexistent within either statute. This definition states that an equity claim is "a claim that is in respect of an equity interest, including a claim for, among others, (a) a dividend or similar payment, (b) a return of capital, (c) a redemption or retraction obligation, (d) a monetary loss resulting from the ownership, purchase or sale of an equity interest or from the rescission, or, in Quebec, the annulment, of a purchase or sale of an equity interest, or (e) contribution or indemnity in respect of a claim referred to in any of paragraphs (a) to (d)."15 According to the Office of the Superintendent of Bankruptcy Canada, this amendment was adopted to "provide greater clarity in subsequent provisions that deal with the rights of shareholders." 16 However, despite this intent to create clarity, the courts have appeared to grapple with the characterization of their role in the classification process, a role which was previously purely discretionary.

\section{Judicial Application of the Debt/Equity Distinction}

Prior to the amendments to the $C C A A$ and the $B I A$, the courts had no statutory guidance as to the definition of an equity claim. Therefore, Canadian courts adopted a contextual, intention-based approach to determine if a hybrid investment constituted debt or equity.

\footnotetext{
${ }^{15}$ CCAA, supra note 9 at s 2. BIA, supra note 9 at s 2.

${ }^{16}$ Office of the Superintendent of Bankruptcy Canada, " Bill C-12: Clause by Clause Analysis - Clauses 1-10" (22 June 2010), online: Office of the Superintendent of Bankruptcy Canada $<$ http://www.ic.gc.ca/eic/site/bsfosb.nsf/eng/br01979.html\#a1> [Bill C-12].
} 
In the leading Canadian decision on the debt/equity distinction-Canada Deposit Insurance Corp. v Canadian Commercial Bank (CDIC v CCB), a 1992 decision of the Supreme Court of Canada, the Court considered the characterization of emergency financial assistance provided to the CCB by a group of lending institutions and the government (the "Participants"). The arrangement provided that the Participants would receive, in return for their financial contribution, warrants to buy up to 75 per cent of CCB's common shares, among other things. Justice Iacobucci stated that in the case of hybrid investments, the court should characterize the investment based on its substance. ${ }^{17}$ He stated: "When a court is searching for the substance of a particular transaction [emphasis added], it should not be too easily distracted by aspects which are, in reality, only incidental or secondary in nature to the main thrust of the agreement."18 In the case of the emergency financial assistance provided by the Participants, although there were equity features existent in the transaction, the transaction constituted debt in substance. Essentially, the court indicated that the characterization should focus on the significant aspects of the investment which work to shape its characterization, rather than those features which are merely incidental and have little effect on the substance of the transaction.

Laying the groundwork for the approach to characterization that should be taken by the courts, Justice Iacobucci stated:

"As in any case involving contractual interpretation, the characterization issue facing this court must be decided by determining the intention of the

\footnotetext{
${ }^{17}$ Canada Deposit Insurance Corp. v Canadian Commercial Bank, [1992] 3 SCR 558 at para 55, (available on WL Can) $[C D I C v C C B]$.

${ }^{18} C D I C$ v CCB, supra note 17 at para 55.
} 
parties to the support agreements [emphasis added]. This task, perplexing as it sometimes proves to be, depends primarily on the meaning of the words chosen by the parties to reflect their intention. When the words alone are insufficient to reach a conclusion as to the true nature of the agreement, or when outside support for a particular characterization is required a consideration of admissible surrounding circumstances may be appropriate."19

The Court found that the words and express terms chosen by the parties in their agreements strongly supported the conclusion that the transaction constituted and was intended to be a loan, rather than a capital investment. ${ }^{20}$ In addition, although the words and express terms chosen by the parties were sufficient to classify the investment, the Court also noted that it was highly unlikely that the warrants would be exercised by the Participants and counted this as a surrounding circumstance, among others, that supported the finding that the financial assistance represented a loan. ${ }^{21}$ The combination of the substance of the transaction and the intention of the parties culminated in a finding that the transaction represented a loan, rather than a capital investment, and would be ranked above equity claims in the insolvency proceedings.

In Re Central Capital Corp., a 1996 decision of the Ontario Court of Appeal, the Court applied the groundwork laid down in CDIC $v$ CCB. The Court of Appeal considered the characterization of an investment of preferred shares with a retraction clause, entitling the holder to retract each preferred share on a fixed date at a fixed price (no dividends were

\footnotetext{
${ }^{19} C D I C v C C B$, supra note 17 at para 52.

${ }^{20} C D I C$ v CCB, supra note 17 at paras 51 and 64.

${ }^{21} C D I C v C C B$, supra note 17 at para 57.
} 
declared on these shares). The company became insolvent prior to the retraction date and was unable to redeem any shares as it would be contrary to applicable law.

In considering the intention of the parties, Justice Laskin looked to the share purchase agreements, conditions attached to the shares, articles of incorporation, and the treatment of the shares in the financial statements to analyze the intention of the parties. ${ }^{22}$ Although these primary considerations supported a finding that the preferred shares represented equity, not debt, the court also considered secondary factors that encompassed the surrounding circumstances of the situation to support the initial finding. In addition, Justice Laskin confirmed that retraction rights did not represent debt claims because "the right of retraction provides for the return of capital not for the repayment of a loan."23

In a subsequent decision, the Ontario Superior Court was called upon to revisit the same issue, reaching a different conclusion. In Re I. Waxman \& Sons Ltd., Justice Pepall confirmed that claims for declared dividends represent debt claims and suggested that there is support for the proposition that an equity claim can transform into a debt claim over time. ${ }^{24}$ Again, with no definition to guide the Court's analysis, this characterization of declared but unpaid dividends was purely at the discretion of the Court.

In September 2009, the amendments to the BIA and the CCAA came into effect. The definition of an "equity claim" and the codification of blanket subordination became operational parts of the CCAA and the BIA. The expectation was that with a clear definition

\footnotetext{
${ }^{22}$ Re Central Capital Corp, 27 OR (3d) 494 at para 121, (available on WL Can), (CA) [Re Central Capital].

${ }^{23}$ Re Central Capital, supra note 22 at para 131.

${ }^{24}$ Re I. Waxman \& Sons Ltd., 89 OR (3d) 427 at paras 20 and 24, (available on WL Can), (Sup Ct).
} 
in place to guide the courts and parties, greater clarity would be achieved. ${ }^{25}$ However, this did not occur. Instead of substituting the intention-based, contextual analysis with an analysis purely of whether the claim fit into the definition of an "equity claim," the courts added the definition-based analysis to the existing test.

In Re Nelson Financial Group Ltd., a post-amendment decision of the Ontario Superior Court of Justice, Justice Pepall once again considered the characterization of a claim for declared but unpaid dividends. Justice Pepall determined that this claim fell within the ambit of the definition of an "equity claim" in section 2 of the CCAA because it represented a claim for "declared but unpaid dividends" 26 and, ultimately, the claim was classified as equity, rather than debt, a decision that varied from her previous finding in Waxman. However, prior to making this finding she conducted a complete contextual analysis of the situation by applying the analysis laid down in $C D I C v C C B$. Justice Pepall considered matters such as the fact that the investors chose to invest in shares despite the option to invest in promissory notes, the fact that they had the right to receive dividends, a condition on the shares that they be ranked ahead of common shareholders (therefore implying that they ranked below credit holders), and the fact that the shares were treated as equity in Nelson's financial statements. ${ }^{27}$

Ultimately, Justice Pepall came to a decision that was consistent with the new amendment. Her decision appears to have been made based on a finding that the claim fell into the ambit of the new "equity claim" definition and this decision varied from her

\footnotetext{
${ }^{25}$ Bill C-12, supra note 16.

${ }^{26}$ Re Nelson Financial Group Ltd., 2010 ONSC 6229 at para 33, (available on WL Can) [Nelson Financial]. See the full definition of an "equity claim" in CCAA, supra note 2 at s 2 . The only other post-amendment decisions on point at the time of writing did not apply the post-amendment law as they involved filings that took place before the amendments came into effect.

${ }^{27}$ Nelson Financial, supra note 26 at para 31.
} 
previous decision in Waxman because of this new analysis. However, the contextual, intention-based analysis provided in this judgement blurred and distorted the actual analysis that is required for these types of claims, rather than increasing the clarity of the analysis as was presumably intended by the amendment. It can be assumed that the intention of the amendment was to make it simpler for all parties involved to easily determine which category, debt or equity, their claim fell within and to eliminate the court's discretionary role in the classification of investments, thereby increasing certainty.

If courts continue to take on this discretionary role in applying the 2009 amendments, the goal of increased clarity and predictability will not be achieved. For example, in Re Nelson Financial Group Ltd., Justice Pepall did not explain why she departed from the pre-amendment case law. Justice Pepall included declared but unpaid dividends in her list of claims that are now "equity claims" in contrast to the pre-amendment case law which treated them as debt. She does not provide an analysis or explain why such a claim is different from a similar claim that has been reduced to a judgment prior to filing. Accordingly, Re Nelson Financial Group Ltd. does not appear to adopt the bright line test introduced by the 20089 amendments and does not provide clarity on when or why the strict definition of "equity claim" should be departed from. If the equity amendment was implemented in order to create a cut-and-dry analysis, ideally it would be applied in this manner, absent from the court's discretion. 


\section{Case Studies on the Debt/Equity Distinction}

The following two case studies illustrate the difficulties, uncertainty, and lack of clarity that result from the current judicial treatment of the debt/equity classification in bankruptcy proceedings for hybrid investments. For each case study, an analysis is provided of the way in which a Canadian court would have treated the situation preamendment and the way in which the situation should be analyzed post-amendment. a. Goyte

The authorized capital of Goyte consists of common shares and preferred shares. The preferred shares have cumulative dividend terms and are redeemable at the option of the shareholder at any time after May 3, 2014. Upon redemption, holders of the preferred shares are owed the par value plus all accrued and unpaid dividends.

According to the articles of incorporation of Goyte, the dividends will be paid "to the extent permitted under the Canada Business Corporations Act (CBCA)". The articles also provide that "dividends shall accrue whether or not they have been declared and whether or not there are profits, surplus or other funds of the Corporation legally available for the payment of the dividends." In addition, the liquidity provisions in the articles provide for priority of the preferred shares' dividends and redemptions ahead of junior securities.

The preferred shareholders of Goyte have exercised their redemption right. However, Goyte does not have sufficient funds to pay these shareholders and/or is prohibited from doing so due to the provisions of the $C B C A$. Goyte has also entered bankruptcy proceedings. The issue at hand is whether the preferred shareholders have an equity claim, subordinating them to Goyte's creditors, or a debt claim. 
Pre-amendment Canadian courts would take a contextual approach to determining whether the Goyte preferred shares represent debt or equity in the context of bankruptcy proceedings. Applying Justice Iacobucci's analysis, the court would first need to analyze the intention of the parties, specifically from their agreements (in this case, the articles of incorporation and the stock purchase agreements). The court could look to any of the following considerations in determining the intention of the parties:

The following considerations indicate a "debt" intention:

- Goyte is obliged to set apart funds for payment of cumulative dividends that they are not able to pay;

- There is a provision for an increasing dividend rate if Goyte fails to make a redemption when due (this is similar to a provision for the payment of interest after the redemption date); and

- The articles suggest that the dividends that accrued but that are unpaid due to section 42 of the CBCA may be considered a debt.

The following considerations indicate an "equity" intention:

- The articles do not provide that after the redemption date and in the event of insolvency, the preferred shareholders could have the right to have Goyte wound up;

- The articles do not provide that on insolvency the preferred shareholders rank pari passu with the creditors of Goyte; 
- The preferred shares are part of the authorized capital of Goyte;

- The preferred shareholders have the right to receive dividends on their shares and vote (well recognized rights of shareholders), in addition to giving written consent on a wide range of matters relating to the governance and financial affairs of Goyte if there are preferred shares outstanding that are convertible into at least $14 \%$ of the common shares of Goyte; and

- The articles do not state that the preferred shareholders cease to be shareholders upon providing a redemption notice.

Pre-amendment, the court would have to balance all of these considerations in determining the true intention of the parties. In addition, as outlined in $C D I C v C C B$, the substance of the transaction must also be considered. The court would have to determine whether the transaction should be classified, in substance, as debt or equity, ignoring the incidental aspects of the preferred shares that might indicate otherwise.

Taken together, the considerations above, derived from the stock purchase agreements, the articles of incorporation, and the conditions attached to the preferred shares, likely indicate that, in substance, the preferred shareholders are shareholders, not creditors of Goyte. When we look at the analysis in practise, we can see the practical problems associated with the contextual approach. With the use of the contextual approach, there is no certainty for any of the parties at any point in the investment, from the time of the transaction until the time of insolvency. Because the court's analysis was focused on the intention of the parties, the substance of the agreement, and any surrounding circumstances, all of which could change over time, the relationship between 
the company and investor and the classification of the investment could also change over time. However, the benefit of the "equity claim" amendment is that it provides certainty at the time of the transaction and does not allow for the classification to change over time.

In a post-amendment analysis, the result of the classification would presumably be the same. However, the difference is the increased clarity and certainty that is derived from this simplified analysis. If the analysis were conducted in the way proposed in this article, it would consist purely of an application of the definition of an "equity claim" to this situation in order to determine if the preferred shares and their associated redemption clause fell within the definition. Section 2 of the $C C A A$ and the BIA state that an "equity claim means a claim that is in respect of an equity interest, including a claim for, among others,...(c) a redemption or retraction obligation."28 It is evident that the claim of the preferred shareholders fits squarely into this definition; the preferred shareholders are making a claim for the redemption value of their shares, a claim that is clearly classified as an equity claim in the definition. No other analysis is required to classify the investment in a way that is consistent with the amendments. With this simple analysis, there is greater clarity and certainty about the way that the investment will be categorized at any point in time. At the time when the preferred shares are issued, for example, Goyte's creditors can know, with certainty, that the preferred shareholders will remain equity claimants upon insolvency even if their redemption right was exercised because an analysis of the intention of the parties and surrounding circumstances, which cannot be predicted, is not

${ }^{28}$ CCAA, supra note 9 at s 2. BIA, supra note 9 at s 2. 
existent in the classification decision. Greater predictability is achieved by essentially removing the court's discretion to classify the investment.

Although the post-amendment courts have appeared to base their classification decisions primarily on the "equity claim" definition rather than the contextual analysis and have reached decisions that are consistent with the equity amendment, the issue with this approach is that the contextual analysis is still conducted in the first place. This results in an unnecessary lack of clarity. When the court's discretion remains a part of the analysis, however inconsequential it may be to the overall analysis, it gives the illusion that the contextual analysis is a significant aspect of the overall classification decision. Let us now turn to a second case study to illustrate how an otherwise simple analysis appears complicated by the addition of a step which ultimately has or should have no bearing on the outcome of the classification.

b. Wuthering Heights

A special purpose trust was created to hold an agricultural property (the "Trust"). Convertible secured debentures (the "Debentures") were issued in relation to the Trust and would be held by an Limited Liability Corporation ("LLC") formed by Wuthering LLC and Heights LLC (both American). At the option of the holder, the Debentures were convertible into $99 \%$ of the units of the Trust at any time after the earliest to occur of:

- A change in law allowing for foreign ownership of the Trust;

- The foreign ownership restrictions applicable to the agricultural property otherwise no longer applying (for example, because of a sale of the agricultural property by the Trust); or 
- The Debentures are held by a Canadian.

It is important to note that the likelihood of any of these four conditions occurring was very low.

The Debentures had a 7\% coupon, payable quarterly. If the Trust had insufficient cash flow to pay the interest, it was entitled to defer the interest for up to two years after the year in which the interest accrued, at which time the issuer would pay the interest inkind by issuing additional debentures. The Debentures had a maturity date of 41 years. In addition, the Debentures had negative covenants which gave the holder approval rights over such matters as the holder may determine are necessary or appropriate to protect or preserve its interests. Lastly, the Debentures were ranked as senior secured indebtedness of the Trust.

The Trust has gone insolvent and the Debentures need to be classified as debt or equity for the purposes of ranking them for bankruptcy proceedings. Any creditors of the Trust would like these convertible debentures to be classified as equity, hence increasing their own distribution in the bankruptcy proceedings, whereas the holders would like the Debentures to be classified as debt, thereby increasing their likelihood of recouping their investment. For the purposes of this example, the holders have not exercised their right to convert the Debentures to units of the Trust.

Once again, a pre-amendment court would take a contextual approach to the classification of this investment, looking primarily at the intention of the parties in addition 
to surrounding circumstances. In this case, the court would look to any of the following considerations in determining the intention of the parties:

The following considerations indicate a "debt" intention:

- The likelihood of any of the conditions for conversion occurring was very low, indicating an intention to avoid conversion to units of the Trust;

- The Debentures were ranked as senior secured indebtedness of the trust, implying that the Debentures would rank above equity in the event of insolvency; and

- The Debentures pay a quarterly coupon

The following considerations indicate an "equity" intention:

- The Debentures had negative covenants which gave the holder approval rights over matters of the Trust (arguably similar to shareholder voting rights); and

- The Debentures were convertible to units of the trust, however unlikely conversion was to occur.

As mentioned in the Goyte case study, the court would have to balance all of the above considerations to determine the true intention of the holders of the Debentures and the trust while also keeping in mind the true substance of the transaction and ignoring the incidental aspects of the investment. Based on the above considerations, it is likely that the court would classify the Debentures as an investment that is, in substance, debt. The court is likely to look at the unlikelihood of the occurrence of the conditions for conversion as a major indicator that the parties intended to form a debtor-creditor relationship. However, 
this prediction, based on the contextual approach, is by no means certain without the guidance of the "equity claim" definition.

In the post-amendment approach to the debt-equity distinction, there would be a much greater amount of certainty. Recalling the definition of an "equity claim," it is "a claim that is in respect of an equity interest."29 When we look at the definition of an "equity interest" in the context of a trust, it is "a unit in the income trust — or a warrant or option or another right to acquire a unit in the income trust — other than one that is derived from a convertible debt." 30 An exception for convertible debt, as is present in this case study, has clearly been carved out in the formulation of this definition. Since it is evident that the Debentures do not fit into the definition of an equity interest, an equity claim clearly cannot be present.

Although this simplified approach came to the same conclusion that the court likely would have rendered after their contextual analysis, the major difference between the two approaches is that the definition-based analysis is certain, simplified, and practical. It is clear and obvious that this situation does not fit into the definition of an "equity interest" and an "equity claim" and will not constitute an equity claim at any point in time, despite any circumstances that occur or intentions to the contrary. With this approach, the decision is not clouded by the unnecessary contextual analysis supplied by the court and the reasoning for the decision is plain and clear, as was intended by the adoption of the amendments.

\footnotetext{
${ }^{29}$ CCAA, supra note 9 at s 2. BIA, supra note 9 at s 2.

${ }^{30} C C A A$, supra note 9 at s 2 . BIA, supra note 9 at s 2 .
} 


\section{Conclusion}

Prior to the "equity claim" amendment, Canadian courts used a contextual approach to classify investments, focusing on the intention of the parties. However, with the introduction of the "equity claim" amendment, confusion looms about the nature of the court's role in the classification decision. Unfortunately, Canadian courts have continued to provide a contextual analysis despite there being no need to do so when an analysis based solely on the definition of an "equity claim" is sufficient. This article has compared the pre and post-amendment case law and used two case studies to illustrate the undue complexity that has been created by layering a contextual analysis on top of the new bright line tests introduced by the 2009 amendments. Simply put, in the context of investment classification decisions for the purposes of bankruptcy proceedings, Canadian courts should limit the scope of their analysis to an inquiry of whether the investment in question falls within the scope of the "equity claim" definition provided in section 2 of the CCAA and the BIA. Only then can bankruptcy costs be limited and can we come closer to a model assumed by the MM Theorem. 